\title{
A Synthetic Chloride Channel Restores Chloride Conductance in Human Cystic Fibrosis Epithelial Cells
}

\author{
Bing Shen ${ }^{2,39}$, Xiang $\mathrm{Li}^{19}$, Fei Wang ${ }^{3}$, Xiaoqiang $\mathrm{Yao}^{2 *}$, Dan Yang ${ }^{1 *}$ \\ 1 Morningside Laboratory for Chemical Biology, Department of Chemistry, The University of Hong Kong, Hong Kong, China, 2 Department of Physiology, The Chinese
} University of Hong Kong, Shatin, Hong Kong, China, 3 Department of Physiology, Anhui Medical University, Hefei, China

\begin{abstract}
Mutations in the gene-encoding cystic fibrosis transmembrane conductance regulator (CFTR) cause defective transepithelial transport of chloride $\left(\mathrm{Cl}^{-}\right)$ions and fluid, thereby becoming responsible for the onset of cystic fibrosis (CF). One strategy to reduce the pathophysiology associated with $\mathrm{CF}$ is to increase $\mathrm{Cl}^{-}$transport through alternative pathways. In this paper, we demonstrate that a small synthetic molecule which forms $\mathrm{Cl}^{-}$channels to mediate $\mathrm{Cl}^{-}$transport across lipid bilayer membranes is capable of restoring $\mathrm{Cl}^{-}$permeability in human CF epithelial cells; as a result, it has the potential to become a lead compound for the treatment of human diseases associated with $\mathrm{Cl}^{-}$channel dysfunction.
\end{abstract}

Citation: Shen B, Li X, Wang F, Yao X, Yang D (2012) A Synthetic Chloride Channel Restores Chloride Conductance in Human Cystic Fibrosis Epithelial Cells. PLoS ONE 7(4): e34694. doi:10.1371/journal.pone.0034694

Editor: Rafael Linden, Universidade Federal do Rio de Janeiro, Brazil

Received August 18, 2011; Accepted March 5, 2012; Published April 13, 2012

Copyright: (c) 2012 Shen et al. This is an open-access article distributed under the terms of the Creative Commons Attribution License, which permits unrestricted use, distribution, and reproduction in any medium, provided the original author and source are credited.

Funding: This study was supported by grants from The University of Hong Kong and the Hong Kong Research Grants Council (HKU 7367/03M and HKU 2/06C). The funders had no role in study design, data collection and analysis, decision to publish, or preparation of the manuscript.

Competing Interests: The authors have declared that no competing interests exist.

*E-mail: yao2068@cuhk.edu.hk (XY); yangdan@hku.hk (DY)

9 These authors contributed equally to this work.

\section{Introduction}

Chloride $\left(\mathrm{Cl}^{-}\right)$ion channels that mediate the flow of $\mathrm{Cl}^{-}$ions through cell membranes play crucial roles in regulating a broad range of biological processes, including ion homeostasis, cell volume regulation, transepithelial transport and the regulation of electrical excitability [1]. The malfunctioning of $\mathrm{Cl}^{-}$channels is implicated in many severe human diseases, most notably cystic fibrosis $(\mathbf{C F})[2,3]$. In $\mathrm{CF}$, mutations in the gene-encoding cystic fibrosis transmembrane conductance regulator (CFTR), a $\mathrm{Cl}^{-}$ channel located at the apical membranes of epithelial cells, causes defective transepithelial transport of $\mathrm{Cl}^{-}$and fluid [4-7]. A general strategy for reducing the pathophysiology associated with $\mathrm{CF}$ mutations is to increase the $\mathrm{Cl}^{-}$permeability of epithelial cells either through CFTR correctors or potentiators or via alternative pathways to compensate for the CFTR $\mathrm{Cl}^{-}$channel defect. Great efforts have been made to develop gene transfer of the GFTR to epithelia [8-11] and therapeutic agents that can activate mutant CFTR genes [12], rescue mutant CFTR trafficking to the apical surface of epithelial cells [13,14], suppress premature stop mutations located in the CFTR gene [15-17] or activate alternative natural $\mathrm{Cl}^{-}$channels [7,17-20]. Denufosol acting on the $\mathrm{P}_{2} \mathrm{Y}_{2}$ receptor opens up an alternative chloride channel resulting in $\mathrm{Cl}^{-}$ion and liquid secretion, and partly compensates for effects caused by the mutant CFTR [19]. However, denufosol has recently failed phase III clinical trials. Therefore, the development of synthetic $\mathrm{Cl}^{-}$channels [21-32] provides a brand new opportunity to enhance transepithelial $\mathrm{Cl}^{-}$secretion for the treatment of CF.

To date, however, most reported synthetic ion channels have been characterized in artificial lipid bilayers, and biological applications of these synthetic $\mathrm{Cl}^{-}$channels to increase the $\mathrm{Cl}^{-}$ permeability of living cells remain poorly explored [33]. Moreover, because most of these synthetic $\mathrm{Cl}^{-}$channel-forming compounds have relatively complicated structures and high molecular weights [22-33], their application to drug discovery is restricted. In this study, we report on a small molecule that can form $\mathrm{Cl}^{-}$channels in plasma membranes of living cells. This synthetic $\mathrm{Cl}^{-}$channel is capable of increasing $\mathrm{Cl}^{-}$conductance in human $\mathrm{CF}$ epithelial cells.

We recently reported that the small molecule $\mathbf{1}$ (Figure 1, panel a) mediates $\mathrm{Cl}^{-}$transport across lipid membranes [34]. The typical single-channel currents we observed for this molecule in giant liposomes confirmed the formation of ion channels [34]. Here, we address the electrophysiological properties and potential functions of this synthetic $\mathrm{Cl}^{-}$channel in living cells.

\section{Results and Discussion}

We first performed inside-out single channel recording, a patch clamp technique [35], to identify the formation of ion channels by compound $\mathbf{1}$ in HEK 293 cells, a widely used cell line in ion channel research. In the presence of $1 \mu \mathrm{M}$ of compound $\mathbf{1}$, the typical single-channel currents were indeed recorded in symmetric N-methylglucamine hydrochloride (NMDG-Cl) solutions (Figure 1, Panel b), indicating that the small molecule can self-assemble into functional ion channels in the cell membranes. Similar to singlechannel recording with compound $\mathbf{1}$ in liposomes, various conductances were observed in the same or different patches, which was anticipated for molecules that self-assemble into ion channels of various sizes [22-33].

We then used the whole-cell configuration of patch clamp technique to examine the electrophysiological properties of the ionic currents induced by compound $\mathbf{1}$ in HEK 293 cells. Whole- 
Synthetic $\mathrm{Cl}-$ Channel Restores $\mathrm{Cl}-$ Conductance

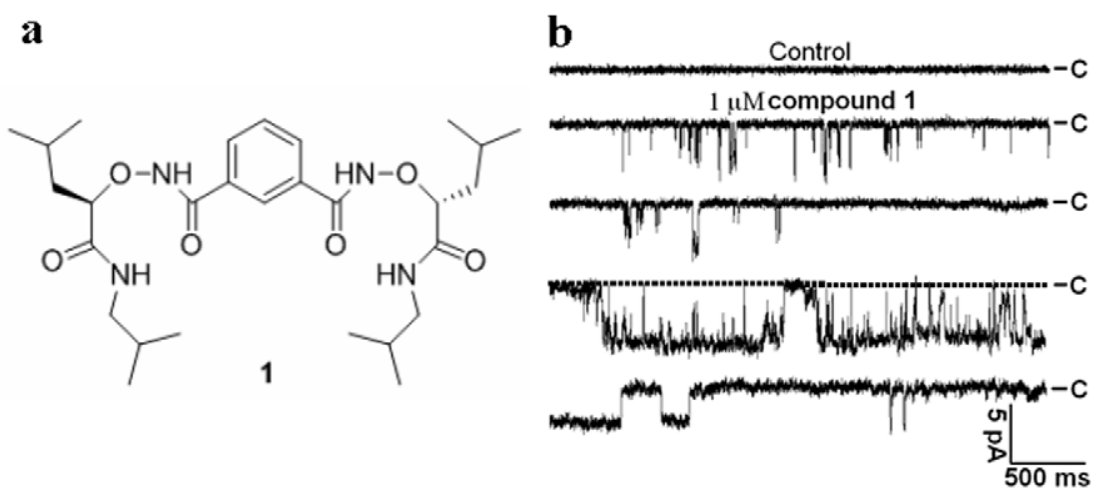

Figure 1. Chemical structure and single channel currents of compound 1 in HEK 293 cells. (a) Chemical structure of compound 1. (b) Representative traces showing single channel currents with DMSO control (top trace) and the application of $1 \mu \mathrm{M}$ compound 1 (lower four traces) at $-60 \mathrm{mV}$ in HEK 293 cells. " $\mathrm{C}$ " represents the base line in which the channel is in the close state.

doi:10.1371/journal.pone.0034694.g001

cell patch clamp recording was first performed in standard intracellular and extracellular solutions (see Methods). While the vehicle $(0.1 \%$ DMSO) had no effect on the whole-cell currents (Figure S1), compound $\mathbf{1}$, even at a low concentration of $1 \mu \mathrm{M}$, induced a large current increase relative to that of the control (Figure 2, Panels a and b). To confirm that the increase in wholecell currents was caused by the formation of synthetic $\mathrm{Cl}^{-}$ channels, we next recorded the whole-cell currents in symmetric bath and pipette solutions of NMDG-Cl. As expected, there was no obvious difference in the whole-cell currents elicited by compound $\mathbf{1}$ when the cations $\left(\mathrm{Na}^{+}, \mathrm{Cs}^{+}\right.$and $\left.\mathrm{Mg}^{2+}\right)$ used in the standard bath and pipette solutions were replaced by the larger NMDG cation (Figure 2, Panels $\mathrm{b}$ and $\mathrm{c}$ ), which is known to be impermeable through most natural cation channels. However, when the NMDG-Cl bath solution was changed from symmetric $150 \mathrm{mM}$ to asymmetric $50 \mathrm{mM}$, the outward current decreased to a remarkable extent and the cell reverse potential $\left(E_{\text {rev }}\right)$ shifted from 0 to $26.99 \pm 1.38(\mathrm{n}=5) \mathrm{mV}$, which is quite close to the value of the $\mathrm{Cl}^{-}$reverse potential $\left(E_{\mathrm{Cl}}\right)(27.76 \mathrm{mV})$ calculated from the Nernst equation. Taken together, these results indicate that the ion channels formed by compound $\mathbf{1}$ are permeable to $\mathrm{Cl}^{-}$ions only, and not to NMDG ions, and the increased whole-cell currents observed in previous experiments can therefore be attributed to the $\mathrm{Cl}^{-}$currents induced by synthetic $\mathrm{Cl}^{-}$channels rather than to a non-specific membrane leak.

We next investigated the anion selectivity of this synthetic $\mathrm{Cl}^{-}$ channel by comparing cell reverse potentials when replacing the extracellular $\mathrm{Cl}^{-}$ions with equimolar $\mathrm{F}^{-}, \mathrm{Br}^{-}, \mathrm{I}^{-}$, and $\mathrm{NO}_{3}{ }^{-}$ ions. The relative permeability ratios against $\mathrm{Cl}^{-}\left(\mathrm{F}^{-}: \mathrm{Cl}^{-}: \mathrm{Br}^{-}\right.$: $\mathrm{I}^{-}: \mathrm{NO}_{3}{ }^{-}$) were determined to be $0.673: 1: 1.121: 1.251: 1.358$ (Figure 3), i.e., the anion transport activity of the synthetic $\mathrm{Cl}^{-}$ channel follows the sequence $\mathrm{F}^{-}<\mathrm{Cl}^{-}<\mathrm{Br}^{-}<\mathrm{I}^{-}<\mathrm{NO}_{3}{ }^{-}$. Meanwhile, the same anion over cation selectivity and relative transport activity toward various anions in patch-clamp studies have also been observed in fluorescence assays performed in liposomes (Figure S2, Panels a and b). Moreover, in our effort to search for potential inhibitors of this synthetic $\mathrm{Cl}^{-}$channel, we examined the effects of a variety of commonly used blockers of natural $\mathrm{Cl}^{-}$ channels. Unfortunately, all the inhibitors tested (DIDS, DPG, NFA, SITS and NPPB) failed to block the whole-cell currents induced by compound $\mathbf{1}$ (Figure S3). This result was not unexpected given that the synthetic $\mathrm{Cl}^{-}$channel may have very different structural features from those of natural ones.

To determine the potential of using compound $\mathbf{1}$ in the treatment of CF, the final step of our analysis involved investigating whether compound $\mathbf{1}$ could be incorporated into the plasma membranes of CF cells and, thereby, function as a $\mathrm{Cl}^{-}$ channel to increase the $\mathrm{Cl}^{-}$permeability of these cells. We recorded the whole-cell currents induced by compound $\mathbf{1}$ in CuFi8 and NuLi-1 cells, [34] which were derived from the human bronchial epithelia of a patient with $\mathrm{CF}$ (CuFi-8, homozygous CFTR $\Delta$ F508 mutant) and a subject without CF (NuLi-1, wild type CFTR), respectively. The application of compound $\mathbf{1}$ induced a gradual increase in the whole-cell currents in the first few minutes, after which the currents became stable for 15 minutes. The currents were persistent even after washing out the cells with control buffer for 30 minutes (Figure 4, Panel b). Interestingly, even at a low concentration of $1 \mu \mathrm{M}$, compound $\mathbf{1}$ induced very large whole-cell currents relative to the basal currents (Figure 4, Panels a and b). The whole-cell currents of the CF cells treated with compound $\mathbf{1}$ displayed a slightly voltage-dependent currentvoltage relationship similar to that seen in HEK 293 cells. Furthermore, panel c of Figure 4 reveals that the addition of forskolin $(2 \mu \mathrm{M})$, an agonist of cAMP, led to a large increase in the $\mathrm{Cl}^{-}$currents of the normal human airway epithelial cells (NuLi-1), whereas the $\mathrm{CF}$ cells $(\mathrm{CuFi}-8)$ exhibited little response to forskolin. In contrast, the addition of $1 \mu \mathrm{M}$ compound $\mathbf{1}$ resulted in an even larger increase in the whole-cell currents of the CuFi-8 cells than that recorded in those of the NuLi-1 cells treated with $2 \mu \mathrm{M}$ forskolin, indicating that compound $\mathbf{1}$ is capable of increasing $\mathrm{Cl}^{-}$ conductance in these CF cells via a novel pathway. Similarly, compound $\mathbf{1}$ also increased $\mathrm{Cl}^{-}$conductance in NuLi-l cells. The compound 1-induced $\mathrm{Cl}^{-}$current was a little smaller than that recorded in CuFi-8 cells. Because compound $\mathbf{1}$ is generated from an $\boldsymbol{\alpha}$-aminoxy acid unit, in considering the possibility of applying compound $\mathbf{1}$ in future, we also examined its toxicity in, for example, immune response in animals. The data showed that compound 1 did not induce mouse immune response, especially in lung tissue (Figures S4 and S5, Methods S1). However, even though compound $\mathbf{1}$ exhibited a very good ability to restore the $\mathrm{Cl}^{-}$permeability of $\mathrm{CF}$ airway epithelial cells and had low toxicity in animals, we still cannot conclude that it can be used to treat $\mathrm{CF}$ in practice. Further experiments based on a $\mathrm{CF}$ animal model should provide better evidence confirming the therapeutic potential of compound $\mathbf{1}$. At this stage, we provide a preliminary report of our findings.

In conclusion, we have demonstrated that compound $\mathbf{1}$ forms functional $\mathrm{Cl}^{-}$channels not only in lipid bilayer membranes of liposomes, but also in those of live cells, as revealed by both single-channel and whole-cell patch clamp experiments. More 

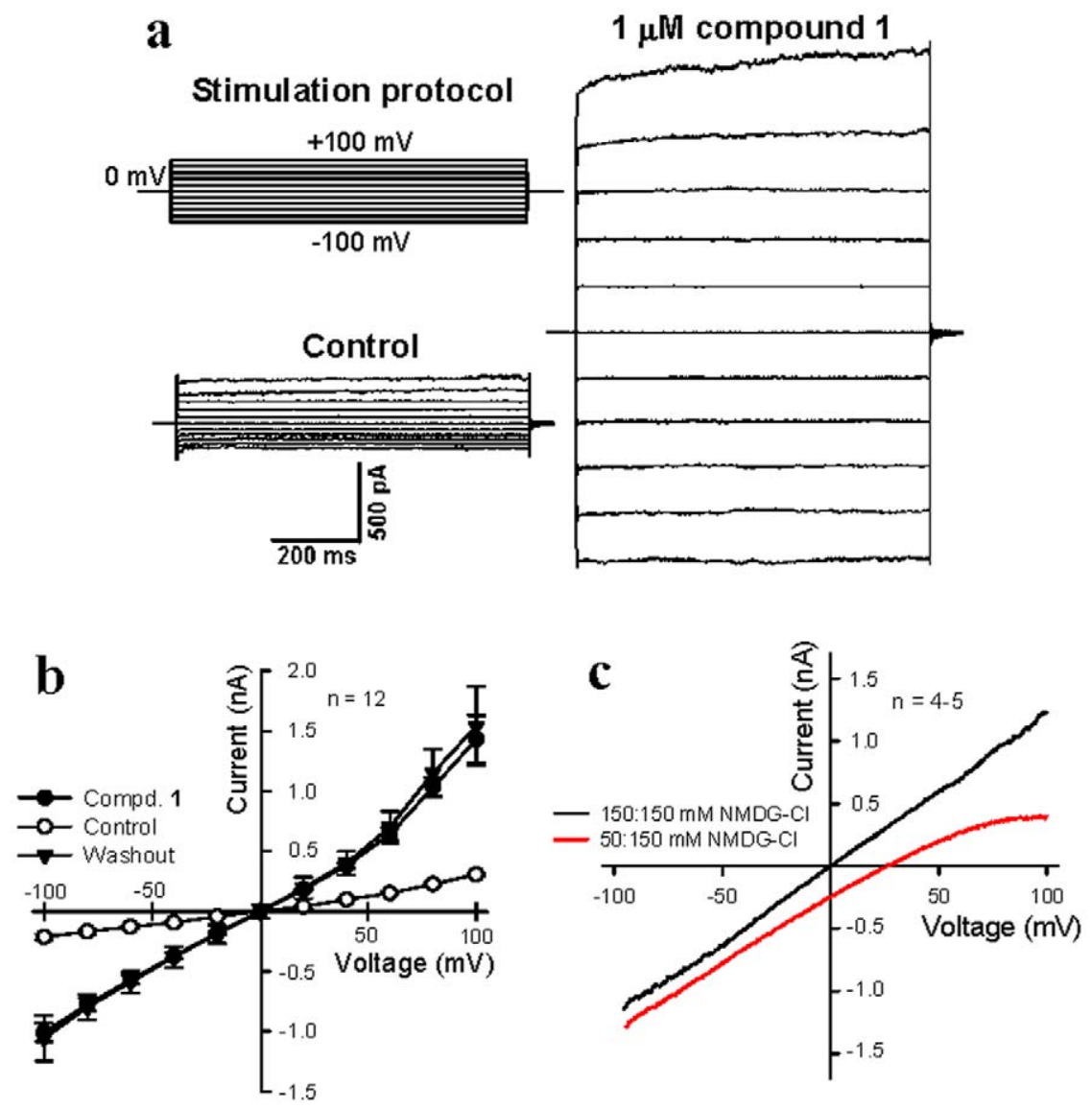

Figure 2. Electrophysiological properties of the ion channels formed by compound 1 in HEK 293 cells. (a) Representative traces showing whole-cell currents in HEK 293 cells. The upper panel shows the stimulation protocol for whole-cell recording, and the lower left panel shows DMSO control currents. The right panel shows whole-cell currents after the application of $1 \mu \mathrm{M}$ compound 1. (b) Current-voltage relationships obtained in the absence $(\bigcirc)$ and presence $(-)$ of $1 \mu \mathrm{M}$ compound 1 and after washout $(\boldsymbol{\Delta})$ with the control bath solution for 30 min in HEK 293 cells. (c) Representative traces showing the whole-cell ramp currents recorded in symmetric $150 \mathrm{mM} \mathrm{NMDG-Cl}$ (black trace) and asymmetric NMDG-Cl with $150 \mathrm{mM}$ in internal and $50 \mathrm{mM}$ in external solutions (red trace). All data are means \pm s.e. $n=5-6$. doi:10.1371/journal.pone.0034694.g002

importantly, compound $\mathbf{1}$ is capable of increasing the $\mathrm{Cl}^{-}$ permeability of CF airway epithelial cells with defects in their native CFTR $\mathrm{Cl}^{-}$channels. In light of these observations, this compound may have therapeutic potential for the treatment of CF lung disease or for treating other diseases that might benefit from increased $\mathrm{Cl}^{-}$transport.

\section{Methods}

\section{Cell culture}

The HEK 293 cell line obtained from the American Type Culture Collection was cultured in DMEM supplemented with $10 \% \mathrm{FBS}, 100 \mathrm{IU} / \mathrm{ml}$ penicillin $\mathrm{G}$ and $0.1 \mathrm{mg} / \mathrm{ml}$ streptomycin. NuLi-1 and CuFi-8 cells, a generous gift from Prof. Joseph Zabner (University of Iowa, Iowa City, IA), were derived from the human bronchial epithelia of a patient without CF (NuLi-1, WT CFTR) and a subject with CF (CuFi-8, homozygous CFTR $\Delta$ F508 mutant), respectively. These cell lines were grown on human placental collagen type VI (Sigma)-coated flasks in BEGM (Cambrex Bio Science, Walkersville, MD) medium, which includes BEGM basal medium and eight SingleQuots of supplements. Cells were grown at $37^{\circ} \mathrm{C}$ in a $5 \% \mathrm{CO}_{2}$ humidified incubator.

\section{Electrophysiology}

The single channel current was recorded using an EPC 9 patch clamp amplifier (HEKA Elektronik, Lambrecht/Pfalz, Germany) in voltage-clamp mode, controlled by Pulse/PulseFit 8.7 software (HEKA) with inside-out patch configuration. Patch pipettes (resistance, 10-20 M $\Omega$ ) were filled with internal pipette solution containing $150 \mathrm{mM}$ NMDG-Cl and $10 \mathrm{mM}$ HEPES (pH 7.2). The bath was composed of symmetric $150 \mathrm{mM} \mathrm{NMDG-Cl}$ and $10 \mathrm{mM}$ HEPES (pH 7.2) with $200 \mu \mathrm{M}$ diphenylamine-2-carboxylic acid that blocks native $\mathrm{Cl}^{-}$channels. After the inside-out recording was achieved without any channel opening, $1 \mu \mathrm{M}$ compound $\mathbf{1}$ was perfused into the bath. The single channel current was recorded continuously and sampled at $4 \mathrm{kHz}$, and was typically low-pass filtered at $0.4 \mathrm{kHz}$ with an 8-pole Bessel filter.

In the whole-cell current recording of the HEK 293, NuLi-1 and $\mathrm{CuFi}-8$ cells in the standard bath $\left(\mathrm{NaCl} 140, \mathrm{CsCl} 5, \mathrm{CaCl}_{2} \mathrm{l}\right.$, $\mathrm{MgCl}_{2} 1$ and HEPES 10 in mM, pH 7.4 with CisOH) and pipette (CsCl 140, $\mathrm{MgCl}_{2}$ 1, HEPES 10, EGTA 5 and $\mathrm{Na}_{2} \mathrm{ATP} 5$ in $\mathrm{mM}$, $\mathrm{pH} 7.2$ with $\mathrm{CsOH}$ ) solutions, the cells were held at $0 \mathrm{mV}$ and voltage steps ranging from -100 to $+100 \mathrm{mV}$ were applied for $800 \mathrm{~ms}$ in $20-\mathrm{mV}$ step increments. In these experiments, the native $\mathrm{K}^{+}$currents were eliminated by using $\mathrm{K}^{+}$-free intra- and 

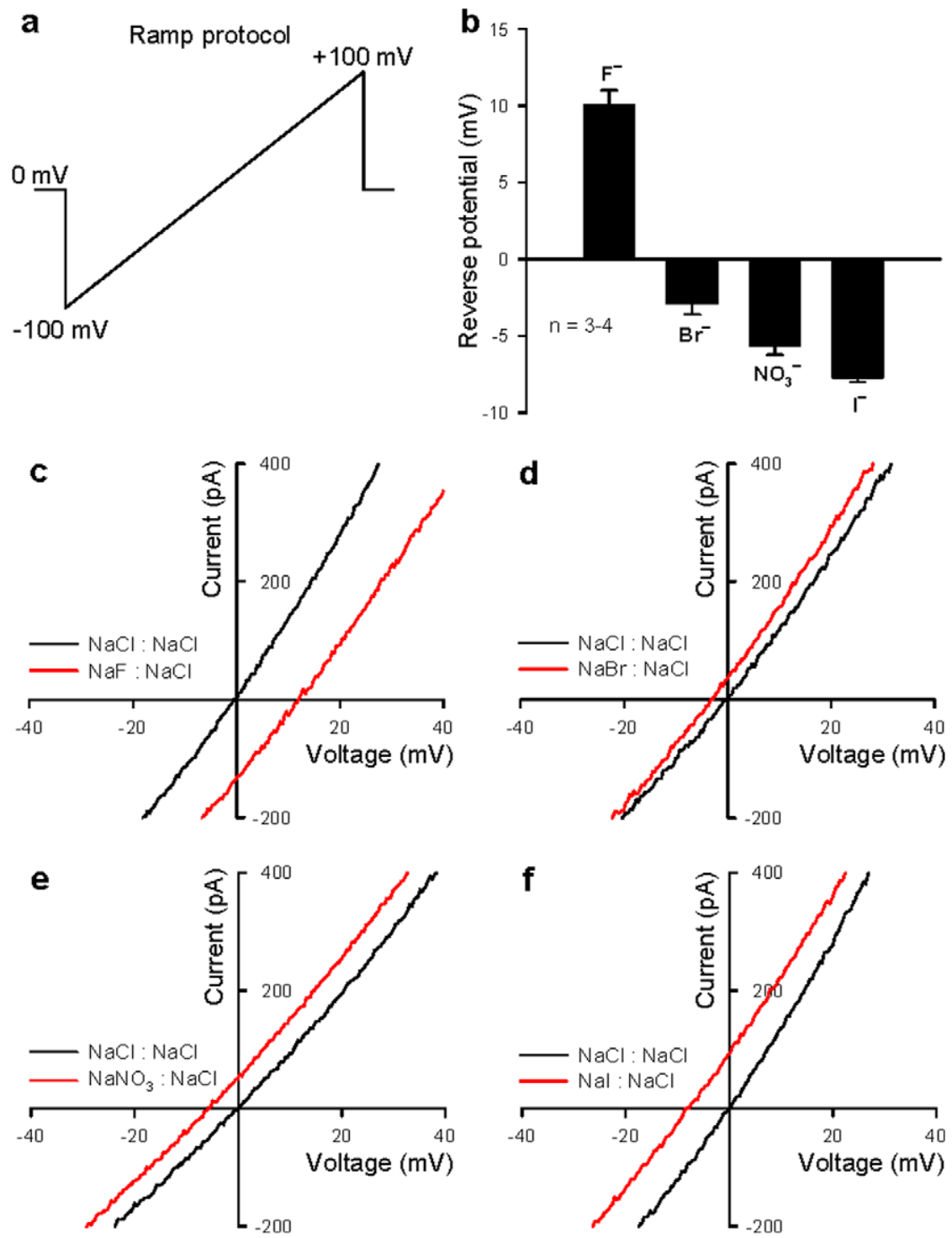

Figure 3. The anion selectivity of synthetic $\mathrm{Cl}^{-}$channel 1 in HEK 293 cells. (a) The ramp stimulation protocol for whole-cell recording. (b) The data summary for reverse potential changes when external solutions were changed from symmetric $150 \mathrm{mM} \mathrm{Cl}^{-}$to $150 \mathrm{mM} \mathrm{F}^{-}, \mathrm{Br}^{-}, \mathrm{NO}_{3}{ }^{-}$and $\mathrm{I}^{-}$, respectively. All data are means \pm s.e. $\mathrm{n}=3-4$. (c-f) Zoomed representative traces showing changes in reverse potential when external solutions

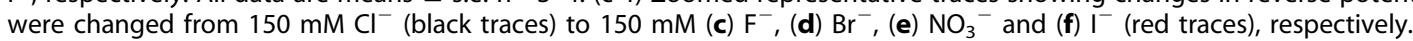

doi:10.1371/journal.pone.0034694.g003

extracellular solutions containing $\mathrm{Cs}^{+}$, and any low threshold native $\mathrm{Ca}^{2+}$ or $\mathrm{Na}^{+}$channels were inactivated by using a holding potential of $0 \mathrm{mV}$. Internal free $\mathrm{Ca}^{2+}$ was chelated by EGTA in pipette solution to prevent $\mathrm{Ca}^{2+}$-dependent channels from being activated. Changes in the whole-cell currents were detected from the same cells before and after exposure to the bath solution containing compound $\mathbf{1}(1 \mu \mathrm{M}, 1 \mathrm{mM}$ stock in DMSO $)$ or forskolin $(2 \mu \mathrm{M}, 2 \mathrm{mM}$ stock in DMSO). Unless indicated otherwise, all control data compared with compound $\mathbf{1}$ were from the $0.1 \%$ DMSO treatment. In ion selectivity experiments, the symmetric solution was first used in both intra- and extracellular sides. The cells were held at $0 \mathrm{mV}$ and whole-cell currents were recorded with a ramp from $-100 \mathrm{mV}$ to $+100 \mathrm{mV}$ for $500 \mathrm{~ms}$. Liquid junction potential was calculated by pClampfit 9.0 software (Axon Instruments, Inc., Sunnyvale, USA) and the corresponding reverse potential was determined. After observing a stable whole-cell current induced by the application of $1 \mu \mathrm{M}$ compound $\mathbf{1}$, the bath solution was replaced by isotonic (adjusted by sucrose) desired extracellular solution also containing $1 \mu \mathrm{M}$ compound 1. In these experiments, all bath solutions containing $200 \mu \mathrm{M}$ diphenylamine-2-carboxylic acid were used to suppress native $\mathrm{Cl}^{-}$channels other than those conducted to investigate the effect of $\mathrm{Cl}^{-}$channel inhibitors. All patch-clamp experiments were performed at room temperature $\left(22-25^{\circ} \mathrm{C}\right)$.

\section{pH-stat HPTS assay}

Typically, $100 \mu \mathrm{L}$ of the HPTS-loaded liposomes (stock solution) was suspended in $1.9 \mathrm{~mL}$ of the corresponding buffer and placed into a fluorimetric cell. HPTS emission at $510 \mathrm{~nm}$ was monitored during simultaneous excitation at wavelengths of 403 and $460 \mathrm{~nm}$. During each experiment, $20 \mu \mathrm{L}$ of a $1 \mathrm{mM}$ THF solution of compound $\mathbf{1}(10 \mu \mathrm{M}$ final $)$ was added through an injection port, followed by the injection of $20 \mu \mathrm{L}$ of $0.5 \mathrm{M}$ aqueous $\mathrm{NaOH}$. The addition of $\mathrm{NaOH}$ caused in increase of ca. $1 \mathrm{pH}$ unit 

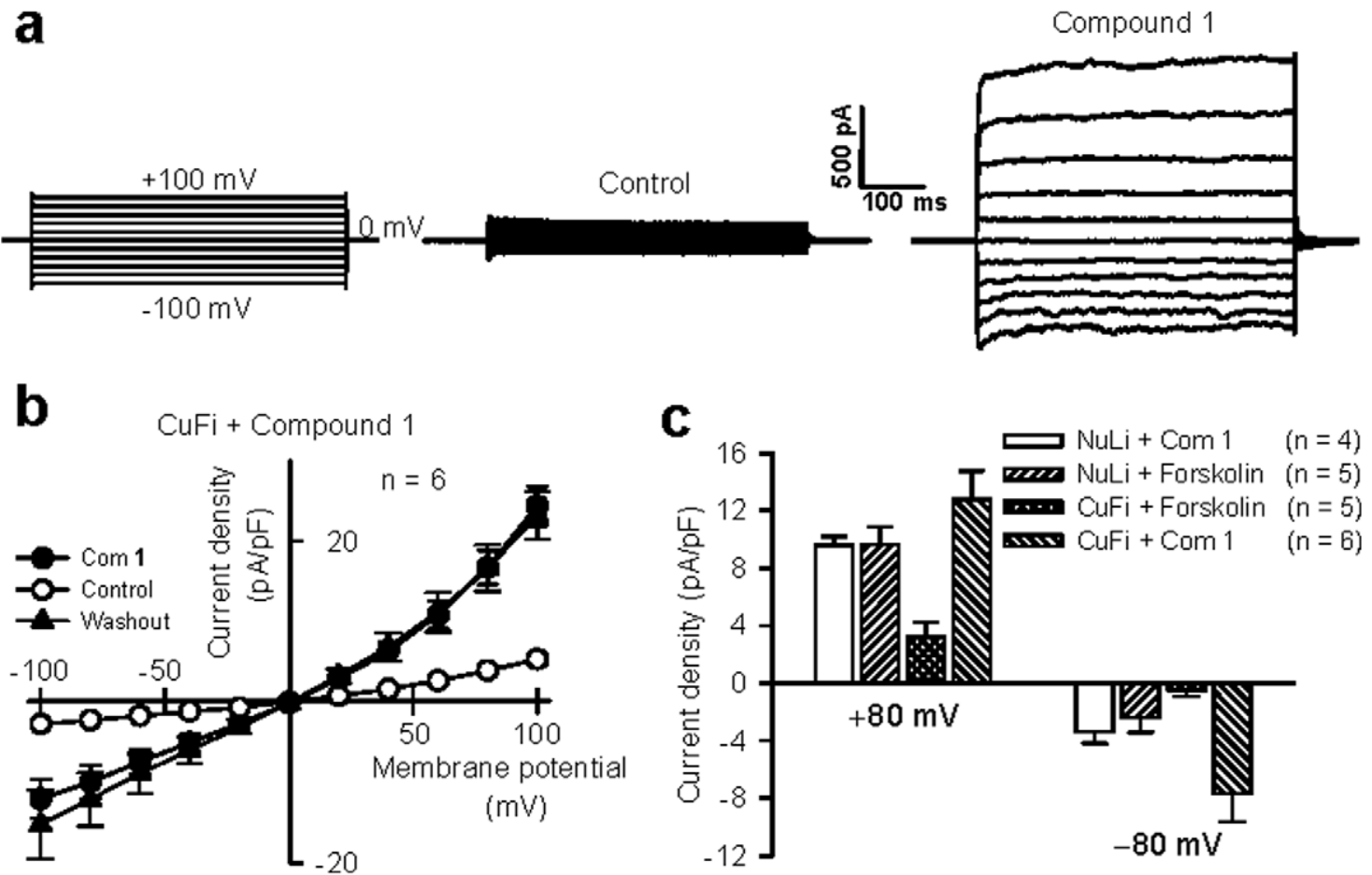

Figure 4. Synthetic $\mathrm{Cl}^{-}$channel formed by compound 1 restored cell $\mathrm{Cl}^{-}$permeability in $\mathrm{CF}$ cells. (a) Representative traces showing whole-cell currents in CF cells. The left panel shows the stimulation protocol for whole-cell recording, and the middle panel shows DMSO control currents. The right panel shows whole-cell currents after the application of $1 \mu \mathrm{M}$ compound 1. (b) The current-voltage relationships obtained in the absence $(\bigcirc)$ and presence $(\mathbf{O})$ of $1 \mu \mathrm{M}$ compound $\mathbf{1}$ and after washout $(\mathbf{\Delta})$ with the control bath solution for 30 min in CuFi-8 cells. (c) Summary of whole-cell currents at $\pm 80 \mathrm{mV}$ induced by forskolin $(2 \mu \mathrm{M})$ and compound $\mathbf{1}(1 \mu \mathrm{M})$ in CuFi-8 and NuLi-1 cells. All data are means \pm s.e. $\mathrm{n}=5-6$. doi:10.1371/journal.pone.0034694.g004

in the extravesicular buffer. The maximal change in dye emission was obtained at the end of each experiment after lysis of the liposomes with a detergent $(40 \mu \mathrm{L}$ of $5 \%$ aqueous Triton $\mathrm{X}-100)$. The final transport trace was obtained from the ratio of the emission intensities monitored at 460 and $403 \mathrm{~nm}$ and was normalized to $100 \%$ of transport.

\section{Supporting Information}

Figure S1 Current-voltage relationships obtained in the absence $(\odot)$ and presence $(\bigcirc)$ of $0.1 \%$ DMSO in HEK 293 cells.

(PDF)

Figure S2 pH-Stat ion transport assays illustrating the ion selectivity of compound 1. All experiments employed suspensions of EYPC liposomes containing the $\mathrm{pH}$-sensitive dye HPTS in a HEPES buffer. The intravesicular solutions were $10 \mathrm{mM}$ HEPES (pH 6.8) and $100 \mathrm{mM} \mathrm{NaCl}$ and extravesicular solutions were $10 \mathrm{mM}$ HEPES $(\mathrm{pH} \mathrm{6.8)}$ and $100 \mathrm{mM} \mathrm{MCl}$ $\left(\mathrm{M}=\mathrm{Na}^{+}, \mathrm{K}^{+}\right.$and $\left.\mathrm{Cs}^{+}\right)$in a. Both the intra- and extravesicular solutions contained $10 \mathrm{mM}$ HEPES (pH 6.8) and 100 or $75 \mathrm{mM}$ $\mathrm{Na}_{\mathrm{n}} \mathrm{X}\left(\mathrm{X}=\mathrm{Cl}^{-}, \mathrm{Br}^{-}, \mathrm{NO}_{3}{ }^{-}, \mathrm{SO}_{4}{ }^{2-}\right)$ in b. At $\mathrm{t}=100 \mathrm{~s}$, a THF solution $(20 \mu \mathrm{L})$ of the testing compound at $10 \mu \mathrm{M}$ final concentration was added to the extravesicular solution; $0.5 \mathrm{M}$ $\mathrm{NaOH}$ solution $(20 \mu \mathrm{L})$ was then added. At $\mathrm{t}=700 \mathrm{~s}, 5 \%$ Triton $\mathrm{X}-100(40 \mu \mathrm{L})$ was added to lyse the liposomes.

(PDF)

Figure S3 The data summary of $1 \mu \mathrm{M}$ compound 1increased whole-cell current densities $(\mathbf{p A} / \mathbf{p F})$ in the absence (control) and presence of $100 \mu \mathrm{M} 4,4^{\prime}$-dithio- cyanatostilbene -2,2' - disulfonic acid (DIDS), $100 \mu \mathrm{M} 4$ acetamido-4' -isothiocyanostilbene-2,2'-disulfonic acid (SITS), $200 \mu \mathrm{M}$ diphenylamine-2-carboxylic acid (DPG), $100 \mu \mathrm{M}$ 5-nitro-2-(3-phenylpropylamino)-benzoic acid (NPPB), and $100 \mu M$ niflumic acid (NFA), respectively, at $\pm 80 \mathrm{mV}$ in HEK 293 cells. The cells were pretreated with the inhibitors, respectively, for $10 \mathrm{~min}$ before the application of $1 \mu \mathrm{M}$ compound 1 . All data are mean \pm s.e. $\mathrm{n}=3-8, P>0.05$ compared to control group.

(PDF)

Figure S4 The data summary of serum TNF- $\alpha$ concentration of mice in the first $24 \mathrm{hrs}$ after intraperitoneal injection with DMSO, lipopolysaccharide (LPS) or compound 1 (Comp 1). DMSO is a negative control because it is the solvent of compound 1. LPS is a well-known endotoxin and capably of eliciting strong immune responses in animals. Here, LPS is a positive control. All data are mean \pm s.e. $n=4-6$ mice, $P>0.05$ compared to DMSO group. $P<0.01$ compared to DMSO group.

(PDF)

Figure S5 The $H$ \& $E$ staining images of mice lung sections in the first $24 \mathrm{hrs}$ after intraperitoneal injection with DMSO, lipopolysaccharide (LPS) or compound 1 (Comp 1). DMSO is a negative control because it is the solvent of compound 1. LPS is a well-known endotoxin and capably of eliciting strong immune responses in animals. Here, LPS is a positive control. The images show inflammatory cells (labeled by blue arrow) infiltration in LPS treatment, but no inflammatory cells can be found in DMSO and compound 1 treatment.

(PDF) 
Methods S1 Immune response test in mouse. (DOC)

\section{Acknowledgments}

We are grateful to Dr. Joseph Zabner of the University of Iowa for providing us with the NuLi-1 and CuFi-8 cells used in this study.

\section{References}

1. Jentsch TJ, Stein V, Weinreich F, Zdebik AA (2002) Molecular structure and physiological function of chloride channels. Physiol Rev 82: 503-568.

2. Jentsch TJ, Hubner CA, Fuhrmann JC (2004) Ion channels: function unravelled by dysfunction. Nat Cell Biol 6: 1039-1047.

3. Quinton PM (2007) Cystic fibrosis: lessons from the sweat gland. Physiology (Bethesda) 22: 212-225.

4. Welsh MJ, Smith AE (1993) Molecular mechanisms of GFTR chloride channel dysfunction in cystic fibrosis. Cell 73: 1251-1254.

5. Quinton PM (1990) Cystic fibrosis: a disease in electrolyte transport. FASEB J 4: 2709-2717.

6. Smith JJ, Karp PH, Welsh MJ (1994) Defective fluid transport by cystic fibrosis airway epithelia. J Clin Invest 93: 1307-1311.

7. Jiang C, Finkbeiner WE, Widdicombe JH, McCray PB, Jr., Miller SS (1993) Altered fluid transport across airway epithelium in cystic fibrosis. Science 262: $424-427$.

8. Welsh MJ (1999) Gene transfer for cystic fibrosis. J Clin Invest 104: 1165-1166.

9. Griesenbach U, Geddes DM, Alton EW (2006) Gene therapy progress and prospects: cystic fibrosis. Gene Ther 13: 1061-1067.

10. Rosenecker J, Huth S, Rudolph C (2006) Gene therapy for cystic fibrosis lung disease: current status and future perspectives. Curr Opin Mol Ther 8: 439-445.

11. Lee TW, Matthews DA, Blair GE (2005) Novel molecular approaches to cystic fibrosis gene therapy. Biochem J 387: 1-15.

12. Cai ZW, Liu J, Li HY, Sheppard DN (2011) Targeting F508del-CFTR to develop rational new therapies for cystic fibrosis. Acta Pharmacol Sin 32: 693-701.

13. Pedemonte N, Lukacs GL, Du K, Caci E, Zegarra-Moran O, et al. (2005) Smallmolecule correctors of defective DeltaF508-CFTR cellular processing identified by high-throughput screening. J Clin Invest 115: 2564-2571.

14. Van Goor F, Straley KS, Cao D, Gonzalez J, Hadida S, et al. (2006) Rescue of DeltaF508-CFTR trafficking and gating in human cystic fibrosis airway primary cultures by small molecules. Am J Physiol Lung Cell Mol Physiol 290: L1117-1130.

15. Wilschanski M, Yahav Y, Yaacov Y, Blau H, Bentur L, et al. (2003) Gentamicininduced correction of CFTR function in patients with cystic fibrosis and CFTR stop mutations. N Engl J Med 349: 1433-1441.

16. Sermet-Gaudelus I, Boeck KD, Casimir GJ, Vermeulen F, Leal T, et al, (2010) Ataluren (PTC124) induces cystic fibrosis transmembrane conductance regulator protein expression and activity in children with nonsense mutation cystic fibrosis. Am J Respir Crit Care Med 182: 1262-1272.

17. Verkman AS, Galietta LJ (2009) Chloride channels as drug targets. Nat Rev Drug Discov 8: 153-171.

18. Kunzelmann K, Mall M (2003) Pharmacotherapy of the ion transport defect in cystic fibrosis: role of purinergic receptor agonists and other potential therapeutics. Am J Respir Med 2: 299-309.

19. Kellerman D, Rossi Mospan A, Engels J, Schaberg A, Gorden J, et al. (2008) Denufosol: a review of studies with inhaled P2Y(2) agonists that led to Phase 3. Pulm Pharmacol Ther 21: 600-607.

\section{Author Contributions}

Conceived and designed the experiments: BS XL XY DY. Performed the experiments: BS XL FW. Analyzed the data: BS XL. Contributed reagents/materials/analysis tools: XY DY. Wrote the paper: BS XL. Critically revised the manuscript: XY DY. Final approval of the version for publication: XY DY.

20. Namkung W, Yao Z, Finkbeiner WE, Verkman AS (2011) Small-molecule activators of TMEM16A, a calcium-activated chloride channel, stimulate epithelial chloride secretion and intestinal contraction. FASEB J 25: 4048-4062.

21. Davis AP, Sheppard DN, Smith BD (2007) Development of synthetic membrane transporters for anions. Chem Soc Rev 36: 348-357.

22. Reddy GL, Iwamoto T, Tomich JM, Montal M (1993) Synthetic peptides and four-helix bundle proteins as model systems for the pore-forming structure of channel proteins. II. Transmembrane segment M2 of the brain glycine receptor is a plausible candidate for the pore-lining structure. J Biol Chem 268: 14608-14615.

23. Oblatt-Montal M, Reddy GL, Iwamoto T, Tomich JM, Montal M (1994) Identification of an ion channel-forming motif in the primary structure of CFTR, the cystic fibrosis chloride channel. Proc Natl Acad Sci U S A 91: 1495-1499.

24. Mitchell KE, Iwamoto T, Tomich J, Freeman LC (2000) A synthetic peptide based on a glycine-gated chloride channel induces a novel chloride conductance in isolated epithelial cells. Biochim Biophys Acta 1466: 47-60.

25. Broughman JR, Mitchell KE, Sedlacek RL, Iwamoto T, Tomich JM, et al. 2001) NH(2)-terminal modification of a channel-forming peptide increases capacity for epithelial anion secretion. Am J Physiol Cell Physiol 280: C451-458.

26. Deng G, Dewa T, Regen SL (1996) A synthetic ionophore that recognizes negatively charged phospholipid membranes. Journal of the American Chemical Society 118: 8975-8976.

27. Jiang C, Lee ER, Lane MB, Xiao YF, Harris DJ, et al. (2001) Partial correction of defective $\mathrm{Cl}(-)$ secretion in cystic fibrosis epithelial cells by an analog of squalamine. Am J Physiol Lung Cell Mol Physiol 281: L1164-1172.

28. Baumeister B, Sakai N, Matile S (2000) Giant artificial ion channels formed by self-assembled, cationic rigid-rod beta-barrels Angew. Chem Int Ed Engl 39: $1955-1958$

29. Gorteau V, Bollot G, Mareda J, Perez-Velasco A, Matile S (2006) Rigid oligonaphthalenediimide rods as transmembrane anion-pi slides. J Am Chem Soc 128: 14788-14789.

30. Schlesinger PH, Ferdani R, Liu J, Pajewska J, Pajewski R, et al. (2002) SCMTR: a chloride-selective, membrane-anchored peptide channel that exhibits voltage gating. J Am Chem Soc 124: 1848-1849.

31. Sidorov V, Kotch FW, Abdrakhmanova G, Mizani R, Fettinger JC, et al. (2002) Ion channel formation from a calix[4] arene amide that binds HCl. J Am Chem Soc 124: 2267-2278.

32. Santacroce PV, Davis JT, Light ME, Gale PA, Iglesias-Sanchez JC, et al. (2007) Conformational control of transmembrane $\mathrm{Cl}(-)$ transport. J Am Chem Soc 129: 1886-1887

33. Matile S, Som A, Sorde N (2004) Recent synthetic ion channels and pores. Tetrahedron 60: 6405-6435.

34. Li X, Shen B, Yao XQ Yang D (2007) A Small synthetic molecule forms chloride channels to mediate chloride transport across cell membranes. J Am Chem Soc 129: 7264-7265.

35. Zabner J, Karp P, Seiler M, Phillips SL, Mitchell CJ, et al. (2003) Development of cystic fibrosis and noncystic fibrosis airway cell lines. Am J Physiol Lung Cell Mol Physiol 284: L844-854. 